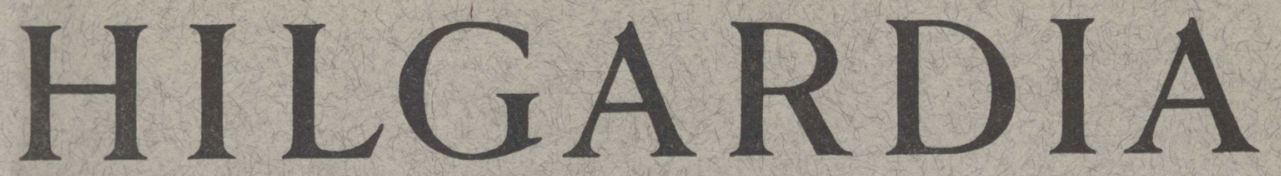

A Journal of Agricultural Science Published by the California Agricultural Experiment Station

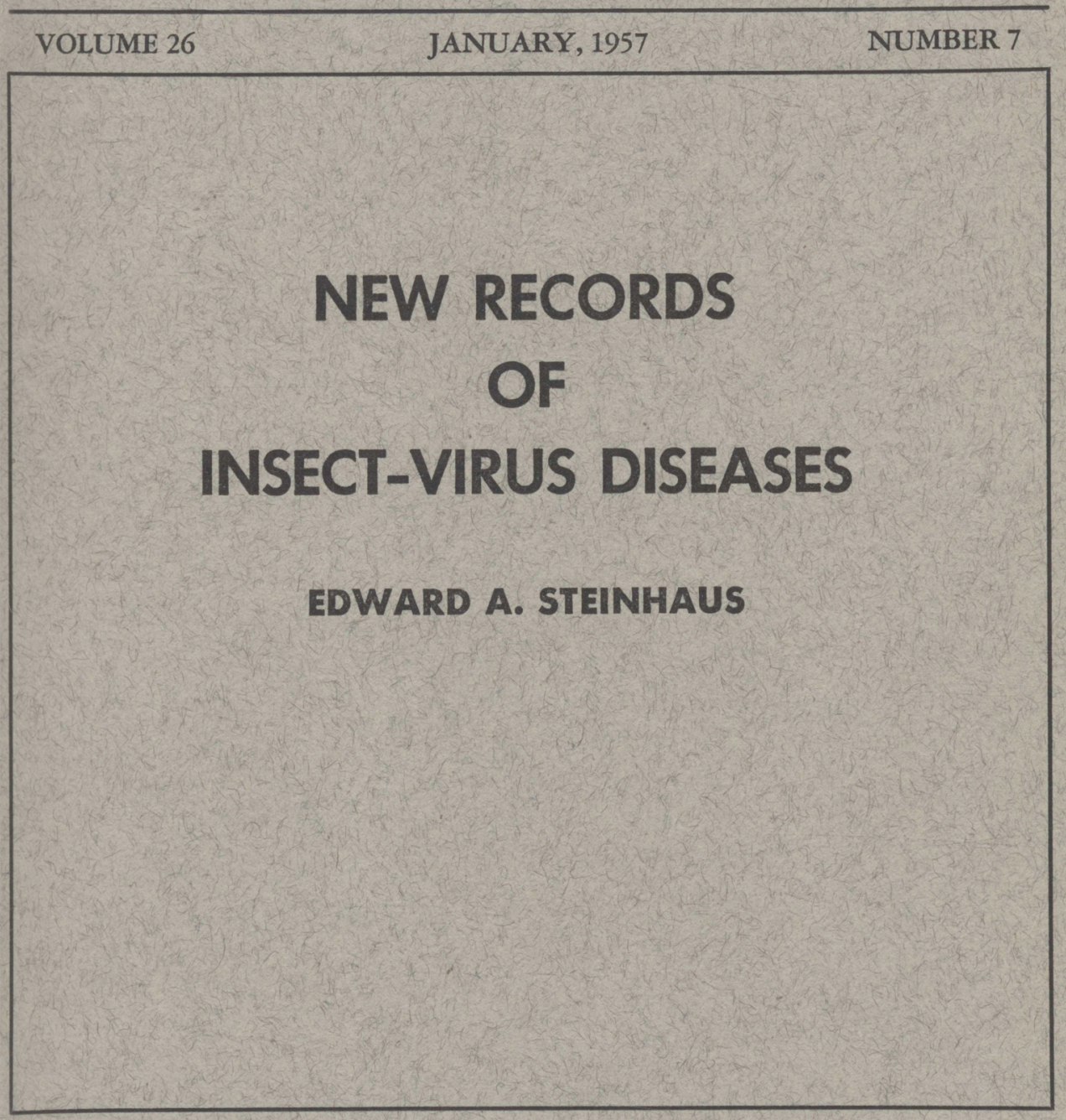

UNIVERSITY OF CALIFORNIA - BERKELEY, CALIFORNIA 


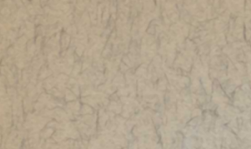

ato

(6)

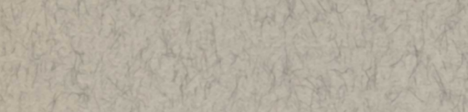

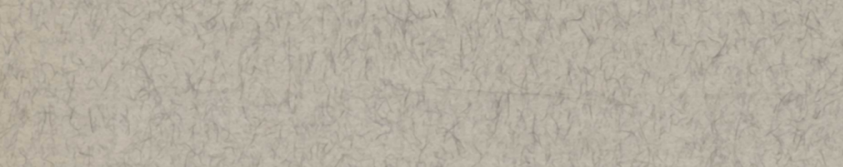

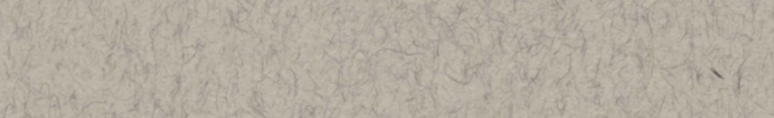

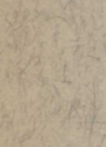

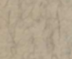

(ing)

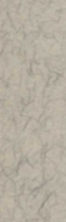

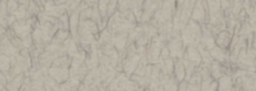

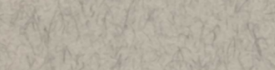




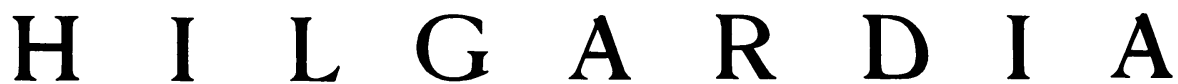

A Journal of Agricultural Science Published by

the California Agricultural Experiment Station

VOL. 26

JANUARY, 1957

No. 7

\section{NEW RECORDS OF INSECT-VIRUS DISEASES}

EDWARD A. STEINHAUS ${ }^{2}$

Since REPORTING (Steinhaus, 1951) ${ }^{3}$ on the diagnosis of specimens of diseased insects received by this laboratory between 1944 and 1950, we have processed a large number of accessions of insects suffering from bacterial, fungus, and protozoan diseases. Among the more interesting accessions were those in which the insects were infected with viruses. Some of the latter constitute new records in that the particular type of virus disease concerned had not heretofore been reported in that particular insect species. Although there was no opportunity to prove the identity and distinctiveness of the viruses by cross-infectivity tests, it is presumed that most of the viruses in these newly recorded hosts are also new.

In addition to reporting these new records, it is the purpose of the present paper to recount seven new instances in which a single insect species is subject to infection by two types of virus; in one case both types occurred simultaneously in the same specimen. The number of insect species known to be susceptible to both a nuclear polyhedrosis virus and a granulosis virus is not great. Nevertheless, a perusal of the literature shows as many as seven insect species recorded, at different times, as being attacked by a nuclear polyhedrosis and a granulosis virus. It is to be hoped that eventually a comparative morphological, developmental, and biochemical study will be made of the two types of virus as they occur in a single host species.

\section{HOSTS OF BOTH POLYHEDROSIS AND GRANULOSIS VIRUSES}

The first insect ${ }^{4}$ to be reported as a host to both types of virus was the cut-

${ }^{1}$ Contribution from the Laboratory of Insect Pathology, Department of Biological Control, University of California, Berkeley. Submitted for publication August, 1956.

${ }^{2}$ Professor of Insect Pathology and Insect Pathologist in the Experiment Station, Berkeley.

${ }^{3}$ See "Literature Cited" for citations, referred to in text by author and date.

4 The first insect to be recorded as a host to a granulosis virus was Pieris brassicae (Linn.) (Paillot, 1926a). This insect is listed by Sweetman (1936) in a list of "Insects Attacked by Virus Diseases." Because all other species included in this list are hosts of polyhedrosis viruses, it is sometimes assumed that Pieris brassicae is also. However, to our knowledge, there is as yet no report of a polyhedrosis in this insect. A possible third type of virus infection, however, has been recorded from this species (Paillot, 1924, 1926b). 
worm Euxoa segetum Schiff. Paillot first described a granulosis virus in larvae of this insect in 1934. In subsequent publications (Paillot, 1935, $1936 a$, and 1937) he described, on the basis of differing pathologies, three granuloses in this insect. He believed each granulosis to be caused by a distinct virus. In the meantime, this same worker (Paillot, 1936b [see also $1936 a]$ ) also reported the presence of a polyhedrosis in the larvae of Euxoa segetum, and pointed out that this disease is sometimes seen in conjunction with one of the granuloses. Furthermore, Smith and Rivers (1956) have reported the presence of a cytoplasmic polyhedrosis in this insect. Incidentally, in the same report these authors also list three instances in which a cytoplasmic, as well as a nuclear polyhedrosis, is known to occur in the same insect species (Heliothis armigera Hüb., Abraxas grossulariata (Linn.), and Tinea pellionella (Linn.)). It might also be mentioned that Xeros (1954) has reported the presence of a "noninclusion" virus in the cytoplasm of fat-tissue cells in larvae of the leatherjacket, Tipula paludosa (Meigen); this same insect species had previously been recorded as the host of a nuclear polyhedrosis of the blood cells (Rennie, 1923; Smith and Xeros, 1954).

A second example of a single insect species being susceptible to both a polyhedrosis virus and a granulosis virus is provided by the spruce budworm, Choristoneura fumiferana (Clem.). Bergold (1949, 1951a) found this insect subject to a nuclear polyhedrosis, and later (Bergold, 1951b) mentioned the existence of a granulosis. This was followed by the report (Bird and Whalen, 1954) of a cytoplasmic polyhedrosis in the same insect. An earlier report (Graham, 1947) of a disease in this insect may have referred to one of the above virus diseases but it cannot be identified with any degree of certainty.

The salt-marsh caterpillar, Estigmene acraea (Drury), is known to be susceptible to a nuclear polyhedrosis (Steinhaus, 1949a), and to a granulosis (Steinhaus and Thompson, 1949).

A granulosis virus attacking the imported cabbageworm, Pieris rapae (Linn.), was reported by Thompson (1951) and described in more detail by Tanada (1953b). In 1954, Tanada described a nuclear polyhedrosis in the same host. According to Tanada, this virus appears to be identical to that responsible for a polyhedrosis in the alfalfa caterpillar, Colias philodice eurytheme Boisduval. There are earlier reports of a polyhedrosis in the cabbageworm, but, since these do not indicate a clear demonstration of polyhedra, Tanada suggests the possibility that the earlier reports may have resulted from observations of the granulosis.

The cosmopolitan armyworm, Pseudaletia unipuncta (Haw.), has been known to be susceptible to a polyhedrosis at least since 1915 when it was reported by Chapman and Glaser (see also Forbes, 1898; and Steinhaus, 1951). Recently, Tanada (1955) reported a granulosis in this insect. (A third virus-a noninclusion type-has also been reported in this insect by Steinhaus (1951) and, in more detail, by Wasser (1952).

What was very probably a polyhedrosis of the alfalfa looper, Autographa californica (Speyer), was observed as early as 1912 (Hyslop, 1912). That this insect does suffer from a polyhedrosis has been proved by the subsequent 
observation of polyhedra in diseased specimens. First knowledge of a granulosis virus affecting the alfalfa looper came in May, 1952, when the diseased larvae were collected near Lancaster, California, by Robert van den Bosch of the University of California at Riverside. An examination of these larvae at that time showed that they were being attacked by a granulosis virus (Steinhaus, unpublished data). In 1953, Hall reported granulosis-infected as well as polyhedrosis-infected loopers from several additional localities in California. We have also observed the granulosis virus in specimens collected in the state of Washington by K. E. Frick.

Recently, Langenbuch (1956), Weiser (1956), and Krieg and Langenbuch (1956) have reported the occurrence of a polyhedrosis in larvae of Cacoecia murinana (Hübner). A granulosis virus had previously been discovered in this insect by Bergold (1948).

\section{NEW RECORDS}

The seven new instances in which a single insect species is subject to both a granulosis and a nuclear polyhedrosis virus are as follows:

\section{Peridroma margaritosa (Haworth)}

A granulosis of the variegated cutworm, Peridroma margaritosa, has been known since 1947 (Steinhaus, 1947; Steinhaus, Hughes, and Wasser, 1949). This virus is shown in figure 1. In May, 1953, our laboratory received from H. L. Chada several dead specimens of the cutworm collected from alfalfa near Denton, Texas. Upon microscopic examination the disintegrating body contents of these insects were filled with polyhedra; the virus was demonstrated with the electron microscope (fig. 2). (The diagnosis was made by C. G. Thompson, then a member of the staff of our laboratory.) To our knowledge, there is no previous record of a polyhedrosis in P. margaritosa.

\section{Junonia coenia Hübner}

The first known virus infection of the buckeye caterpillar, Junonia coenia, was the granulosis reported by Steinhaus and Thompson in 1949 (see fig. 3). In May, 1955, K. M. Hughes and Susan Tuttle, of our staff, in the course of routine infectivity tests using Junonia, observed the death of one of the control larvae. Upon microscopic examination the tissues of this specimen were found to contain large numbers of polyhedra. This material was used to infect other Junonia larvae. From these, electron micrographs of dissolved polyhedra were made, revealing a typical rodshaped virus (fig. 4).

\section{Laphygma exigua (Hübner)}

A virus (fig. 6) responsible for a polyhedrosis in the beet armyworm, Laphygma exigua, has been reported previously (Steinhaus, $1949 b$ [p. 209], 1951). In September, 1955, the author received from J. E. Swift, Extension Entomologist for the University of California, several specimens of the beet armyworm which he had found diseased near Modesto, California. Upon 
microscopic examination, they disclosed infection with a granulosis virus. This was confirmed with the electron microscope (fig. 5).

\section{Laphygma frugiperda (J. E. Smith)}

The fall armyworm, Laphygma frugiperda, was among those listed by Chapman and Glaser (1915) as being susceptible to a polyhedrosis virus. Allen (1921) observed an outbreak of the disease in Mississippi, and confirmed the presence of polyhedra in the diseased insects. The virus itself has not been demonstrated by electron micrography. In May, 1956, we received diseased specimens of this armyworm from Carlos Carmona in Medellin, Colombia. They had been collected from corn in Valle del Cauca. We were able to determine that some of the larvae had been killed by a granulosis virus (fig. 9). Capsules were abundant in the disintegrating tissues.

\section{Sabulodes caberata (Guenée)}

The susceptibility of the omnivorous looper, Sabulodes caberata, to a granulosis virus has been previously reported (Hughes and Thompson, 1951). In September of 1954 (and possibly as early as 1950), K. M. Hughes of our laboratory observed occasional diseased specimens of the looper, the tissues of which contained numerous polyhedral bodies. Upon examining preparation of these bodies with the electron microscope we have been able to demonstrate the presence of a virus within them.

\section{Chorizagrotis auxiliaris (Grote)}

In June, 1954, J. L. Hoerner sent us 20 dead specimens of the army cutworm, Chorizagrotis auxiliaris, which he had collected near Monte Vista, Colorado. The larvae were collected from fields in which the incidence of obvious disease at any one time ran from 1 or 2 per cent of the larvae to as high as 15 to 18 per cent. When larvae were held in cages the incidence ran much higher. Upon examination in our laboratory the larvae were found suffering from a polyhedrosis (fig. 8). In May, 1955, we received from W. F. Barr of the University of Idaho, several diseased specimens of the army cutworm collected near Grangeville, Idaho. Examination of the disintegrating tissues by ordinary light microscopy indicated that a granulosis virus (fig. 7) was present. This was definitely confirmed when examined with an electron microscope.

\section{Double Infection}

To our knowledge three previous instances have been reported (Paillot, $1936 a$; Tanada, 1953a; 1956) in which a nuclear polyhedrosis virus infection appeared simultaneously with a granulosis virus infection in the same insect specimen. (Smith and Xeros, 1953, have reported the presence of both nuclear and cytoplasmic polyhedroses in the same individuals.) Paillot briefly describes such an occurrence in the case of the cutworm Euxoa segetum Schiff. From Paillot's account, however, it is not clear whether the double infection was observed in cutworms in nature or whether it was induced in the laboratory. Tanada observed a granulosis and a polyhedrosis together in larvae of 
the imported cabbageworm, Pieris rapae (Linn.), reared in the laboratory. He also found field-collected specimens of the armyworm, Pseudaletia unipuncta (Haw.), to be infected with both a granulosis and a polyhedrosis virus.

In May, 1956, we received from G. W. Thomas of the University of Missouri several larvae of the bronzed cutworm, Nephelodes emmedonia (Cram.), collected in the field in Clay County, Missouri. The tissues and body fluids of one of these larvae contained large numbers of polyhedra, as well as the capsules characteristic of a granulosis infection. Observations of this phenomenon by light and phase microscopes were confirmed with the electron microscope (figs. 10 and 11). Although one is tempted to speculate on the possible significance of such a case of double infection (as to the possible origin and relationship between the two viruses, for example), we can only assume at this point that it represents an instance of two viruses infecting a single host at about the same time. The possibility that one of the two viruses was latent in the host, and that exogenous infection by the second caused the first to become activated, cannot be ruled out.

It should be pointed out that this is the first record of a granulosis virus in the bronzed cutworm. That the insect is susceptible to a polyhedrosis virus has been known since at least 1937 (Walkden, 1937; see also Steinhaus, $1949 a$, page 470 ).

\section{OTHER NEW RECORDS}

In addition to the new records just reported several additional cases of unrecorded virus infections have been observed in our laboratory.

Polyhedroses. In May, 1951, we received from V. D. Roth of Oregon State College a small branch of ponderosa pine infested with larvae of the sawfly Neodiprion mundus Rohwer. The diseased larvae were found to contain polyhedra, but the virus itself was not demonstrated.

Ray F. Smith, in November, 1952, submitted to us a diseased larva of Hemileuca tricolor Packard, collected on mesquite about 40 miles east of Ajo, Arizona. A diagnosis of this specimen showed it to have been killed by a polyhedrosis, and the virus (fig. 12) was revealed with the aid of the electron microscope.

From Chile, in January, 1953, R. Cortés sent us for diagnosis several larvae of Rachiplusia nu Guen. When examined by C. G. Thompson in this laboratory, the insect was found to be suffering from a polyhedrosis (fig. $15)$.

A number of dead larvae of the tobacco budworm, Heliothis virescens (Fabr.), received in April, 1954, from L. D. Newsom in Louisiana were found to contain polyhedra, the insects apparently having died of a polyhedrosis (fig. 16).

In July, 1955, we received from W. F. Chamberlain several diseased specimens of the lespedeza webworm, Tetralopha scortealis (Led.). The larvae arrived showing symptoms typical of a polyhedrosis, which was confirmed by microscopic examination. 
A mixture of disintegrating specimens of Anticarsia gemmatilis and Xylomyges sp. received from J. E. Wille, in Peru, was found filled with polyhedra. Either or both of the species concerned may have been infected.

Granuloses. To our knowledge, no member of the family Megalopygidae has previously been reported as susceptible to a virus. In November, 1955, H. A. Dean of the Texas Agriculture Experiment Station at Weslaco, Texas, sent us diseased specimens of the puss caterpillar, Megalopyge opercularis (J. E. Smith). The insect was occurring in large numbers on citrus and other plants. However, considerable numbers of the caterpillar died of disease which, according to Dean, "appeared to be one of the most important biological controls" of the insect. Our examination of the infected larvae revealed the presence of a granulosis virus.

Diseased larvae of the tortricid moth Amelia pallorana (Rob.) were sent to this laboratory in June, 1951, by George E. Bohart of the U.S.D.A. in Logan, Utah. According to Bohart, the insect can be a serious pest of seed alfalfa in certain areas of Utah. The specimens sent us were collected from a population in which the disease was appearing in epizootic proportions. Upon receipt, they were diagnosed by C. G. Thompson and K. M. Hughes as being infected with a granulosis virus. Larvae of a subsequent generation, sent to us in August, were also heavily infected with the virus (fig. 13).

The susceptibility of the red-banded leaf roller, Argyrotaenia velutinana (Walker), has been previously reported (Sibold, 1950; Wasser and Steinhaus, 1951). These reports were from Virginia. It should be recorded that apparently the same virus was found in the same insect sent to us from Missouri by E. R. Oatman, in 1951.

Diseased specimens of the lodgepole pine needleminer, Recurvaria milleri Busck, a serious pest in the Sierra Nevada Mountains of California, were submitted to us in 1951 by G. R. Struble and J. H. McLeod. The larvae, collected in Yosemite National Park, were found infected with an undescribed granulosis virus. Similar larvae of the same species collected by Mr. Struble near Tanaya Lake, California, in 1953, also were heavily infected with apparently the same granulosis virus (fig. 14).

\section{SUMMARY}

Among the numerous accessions of diseased insects received for the purpose of diagnoses by this laboratory since our last diagnostic report in 1951, were a considerable number of specimens infected or killed by viruses. Of the insect hosts concerned, at least 15 have not previously been recorded as host to the particular type of viruses herein reported as new records. These new records furnish seven new instances in which a single insect species is subject to infection by both a granulosis virus and a nuclear polyhedrosis virus. In the case of one insect (the bronzed cutworm, Nephelodes emmedonia (Cram.)), a polyhedrosis virus infection appeared naturally and simultaneously with a granulosis virus infection in the same specimen.

In this paper we are intentionally avoiding speculation as to the possible significance of the susceptibility of a given insect species to both types (poly- 
hedrosis and granulosis) of virus, or as to the possible relationship between the two types of virus as it may pertain to their phylogeny or their "life cycles."

\section{ACKNOWLEDGMENTS}

The author wishes to acknowledge the assistance of Miss Susan Tuttle, Senior Laboratory Technician, who prepared most of the electron micrographs used in this paper. Certain others (figs. 2, 3, 4, 13, 14) were made by Mr. K. M. Hughes, whose help in this regard is gratefully appreciated.

\section{LITERATURE CITED}

Alisen, H. W.

1921. Notes on a bombylid parasite and a polyhedral disease of the southern grass worm, Laphygma frugiperda. Jour. Econ. Ent. 14:510-11.

BERGOLD, G. H.

1948. Über die Kapselvirus-Krankheit. Ztschr. Naturforsch. 3b:338-42.

1949. The polyhedral disease of the spruce budworm, Choristoneura fumiferana Clem. Dominion Dept. Agr., Forest Insect Investigations Bi-Monthly Progress Rpt. 5, p. 2.

1951a. The polyhedral disease of the spruce budworn, Choristoneura fumiferana (Clem.) (Lepidoptera: Tortricidae). Canadian Jour. Zool. 29:17-23.

1951b. Fortschritte und Probleme auf dem Gebiete der Insektenviren. Ztsehr. Angew. Ent. $33: 267-78$.

BiRd, F. T., and M. M. WhaleN

1954. A nuclear and a eytoplasmic polyhedral virus disease of the spruce budworm. Canadian Jour. Zool. 32:82-86.

Chapman, J. W., and R. W. Glaser

1915. A preliminary list of insects which have wilt, with a comparative study of their polyhedra. Jour. Econ. Ent. 8:140-50.

Forbes, S. A.

1898. Note on a new disease of the army worm (Leucania unipuncta Haworth). 20th Rpt. State Entomologist on Noxious and Beneficial Insects of the State of Illinois. Pp. 106-09.

Graham, K.

1947. Studies on the spruce budworm in Ontario. Pathological investigations. Dominion Dept. Agr., Forest Insect Investigations Bi-Monthly Progress Rpt. 2, p. 3.

HALI, I. M.

1953. The role of virus diseases in the control of the alfalfa looper. Jour. Econ. Ent. 46:1110-11.

Hughes, K. M., and C. G. Thompson

1951. A granulosis of the omnivorous looper, Sabulodes caberata Guenée. Jour. Infect. Dis. $89: 173-79$.

HySLOP, J. A.

1912. The alfalfa looper. U. S. Dept. Agr., Bur. Ent. Bul. 95:109-18.

KRIEG, A., and R. LANGENBUCH

1956. Über einige neue Insekten-Virosen. Entomophaga 1:92-93.

LANGENBUCH, R.

1956. Eine verbesserte und zeitsparende Methode zur Färbung von Viruseinschlusskörpern (Polyedern) in Schnittpräparaten mit Eisenhämatoxylin. Mikroskopie $10: 344-48$.

Paillot, A.

1924. Sur une nouvelle maladie des chenilles de Pieris brassicae et sur les maladies du noyau chez les insectes. Acad. des Sci. [Paris] Compt. Rend. 179:1353-56. 
1926a. Sur une nouvelle maladie du noyau ou grasserie des chenilles de Pieris brassicae et un nouveau groupe de micro-organismes parasites. Acad. des Sci. [Paris] Compt. Rend. 182:180-82.

$1926 b$. Contribution à l'étude des maladies à virus filtrant chez les insectes. Un nouveau groupe de parasites ultramicrobiens: les Borrellina. Inst. Pasteur [Paris] Ann. $40: 314-52$.

1934. Un nouveau type de maladie à ultravirus chez les insectes. Acad. des Sci. [Paris] Compt. Rend. $198: 204-05$.

1935. Nouvel ultravirus parasite d'Agrotis segetum provoquant une prolifération des tissues infectés. Acad. des Sci. [Paris] Compt. Rend. 201:1062-64.

1936a. Contribution à l'étude des maladies à ultravirus des insectes. Ann. des Épiphyt. Phytogénét. 2:341-79.

1936b. Nouveau type de maladies à polyèdres ou polyédries observé chez les chenilles d'Euxoa (Agrotis) segetum Schiff. Acal. des Sei. [Paris] Compt. Rend. 202: 254-56.

1937. Nouveau type de pseudo-grasserie observé chez les ehenilles d'Euxoa segetum. RenNie, J. Acad. des Sci. [Paris] Compt. Rend. 205:1264-66.

1923. Polyhedral disease in Tipula paludosa (Meigen). Roy. Phys. Soc., Edinb., Proc. $20: 265-67$.

Sibold, N. V.

1950. Granulosis of the red-banded leaf roller. Virginia Jour. Sci. 1:266.

SMITH, K. M., and C. F. Rivers

1956. Some viruses affecting insects of economic importance. Parasitology 46:235-42.

SMith, K. M., and N. Xeros

1953. Studies on the cross-transmission of polyhedral viruses: experiments with a new virus from Pyrameis cardui, the painted lady butterfly. Parasitology $43: 178-85$.

1954. An unusual virus disease of a dipterous larva. Nature 173:866-67.

Steinhaus, E. A.

1947. A new disease of the variegated cutworm, Peridroma margaritosa (Haw.) Science $106: 323$.

1949a. Principles of insect pathology. MeGraw-Hill Book Co., 757 pp.

1949b. Nomenclature and classification of insect viruses. Bact. Rev. 13:203-23.

1951. Report on diagnoses of diseased insects 1944-1950. Hilgardia 20(22):629-78.

Steinhaus, E. A., K. M. Hughes, and H. B. Wasser

1949. Demonstration of the granulosis virus of the variegated cutworm. Jour. Bact. $57: 219-24$.

Steinhaus, E. A., and C. G. Thompson

1949. Granulosis disease in the buckeye caterpillar, Junonia coenia (Hübner. Science $110: 276-78$.

SWEETMAN, H. L.

1936. The biological control of insects. Comstock Publishing Co., Ithaca, N.Y. 461 pp.

TANADA, Y.

1953a. Infectious diseases of the imported cabbageworm with special reference to virus diseases. Univ. California, Berkeley. (Ph.D. dissertation, 137 pp.)

1953b. Description and characteristics of granulosis virus of the imported cabbageworm. Hawaiian Ent. Soc. Proc. $15: 235-60$.

1954. A polyhedrosis virus of the imported cabbageworm and its relation to a polyhedrosis virus of the alfalfa caterpillar. Amer. Ent. Soc. Ann. 47:553-74.

1955. Notes and exhibitions. Hawaiian Ent. Soc. Proc. 15:377.

1956. Some factors affecting the susceptibility of the armyworm to virus infections. Jour. Econ. Ent. $49: 52-57$.

Thompson, C. G.

1951. A granulosis of the imported cabbageworm. Jour. Econ. Ent. 44:255.

WALKDEN, H. H.

1937. Notes on the life history of the bronzed cutworm in Kansas. Kansas Ent. Soc. Jour. 10:52-59. 
WASSER, H. B.

1952. Demonstration of a new insect virus not associated with inclusion bodies. Jour. Bact. $64: 787-92$.

Wasser, H. B., and E. A. Steinhaus

1951. Isolation of a virus causing granulosis of the red-banded leaf roller. Virginia Jour. Sci. 2:51-93.

WEISER, J.

1956. Die Krankheiten des Tannentriebwicklers, Cacoecia murinana Hb. in der Mittelslowakei (ČSR). Ztschr. f. Pflanzenkrank. (Pflanzenpathologie) und Pflanzenschutz 63:193-97.

Xeros, N.

1954. A second virus disease of the leatherjacket, Tipula paludosa. Nature 174:562.

The photographs used to illustrate this paper were made in the course of routine diagnostic examinations, with no attempt made to obtain electron micrographs of the quality desirable for morphological studies. In most instances, the amounts of infectious material retained were insufficient to make new preparations and photographs for this paper. In size, the virus rods were found to be in accordance with the usual range of dimensions of the known rod-shaped insect viruses, most of them averaging between 40 to 65 by 245 to 345 millimicrons. 

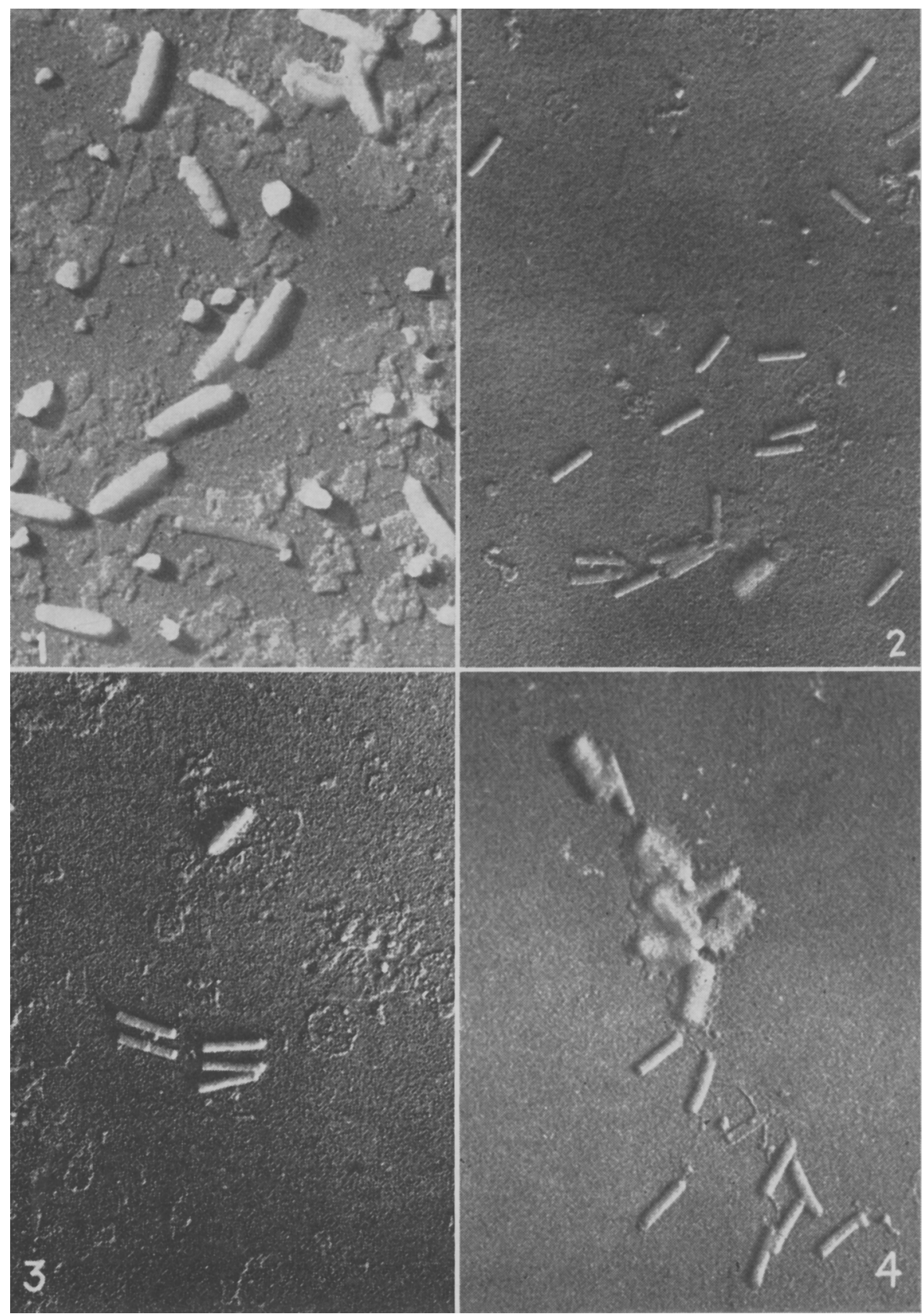

Fig. 1. An electron micrograph of a granulosis virus of Peridroma margaritosa. Virus still retained in intimate membrane. (This, and all other electron microscope preparations shown in this paper were shadowed with palladium.)

Fig. 2. An electron micrograph of a polyhedrosis virus of Peridroma margaritosa.

Fig. 3. An electron micrograph of a granulosis virus of Junonia coenia.

Fig. 4. An electron micrograph of a polyhedrosis virus of Junonia coenia.

Note bundles as well as individual rods. 


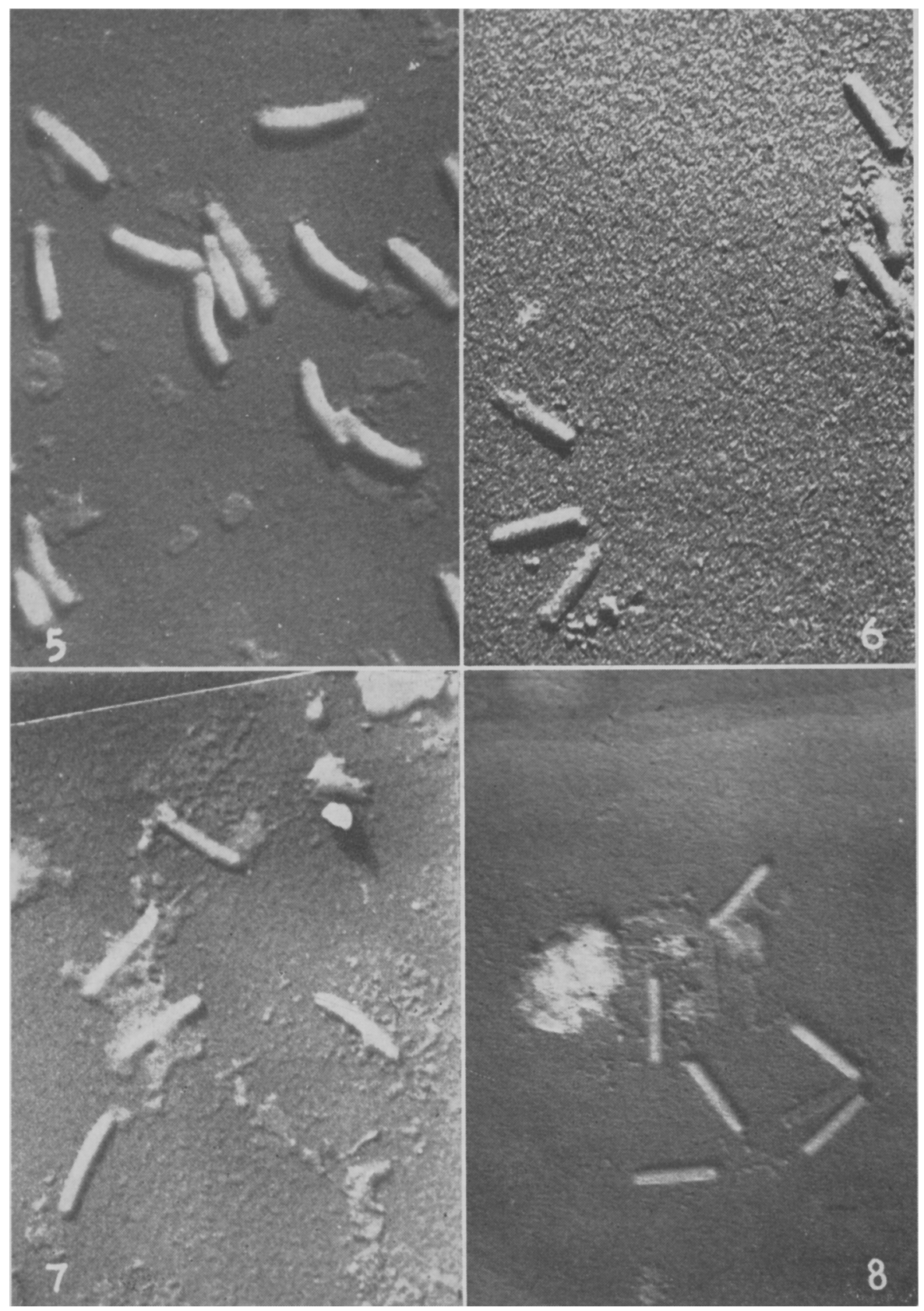

Fig. 5. An electron micrograph of a granulosis virus of Laphygma exigua.

Fig. 6. An electron micrograph of a polyhedrosis virus of Laphygma exigua.

Fig. 7. An electron micrograph of a granulosis virus of Chorizagrotis auxiliaris. Fig. 8. An electron micrograph of a polyhedrosis virus of Chorizagrotis auxiliaris. 


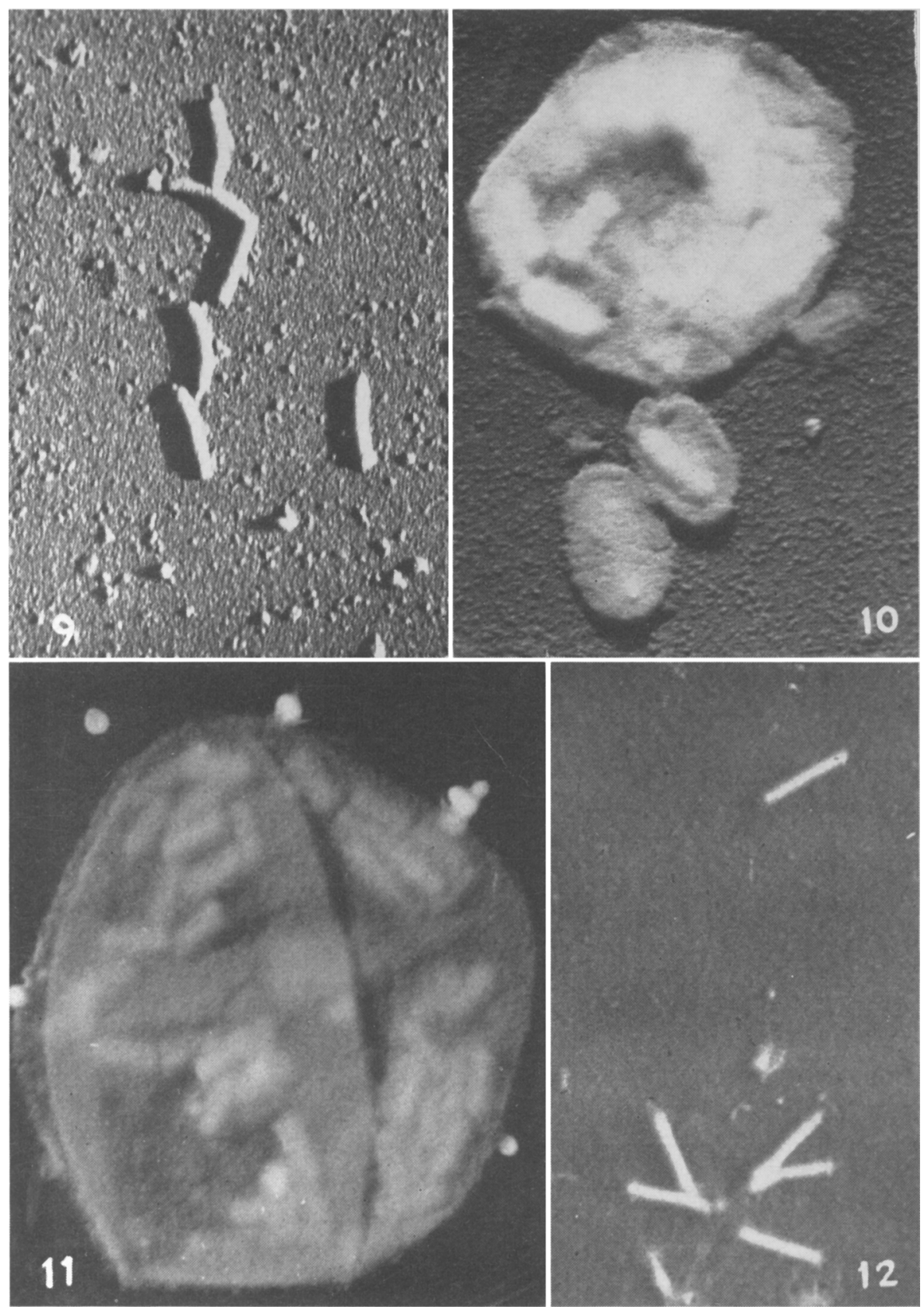



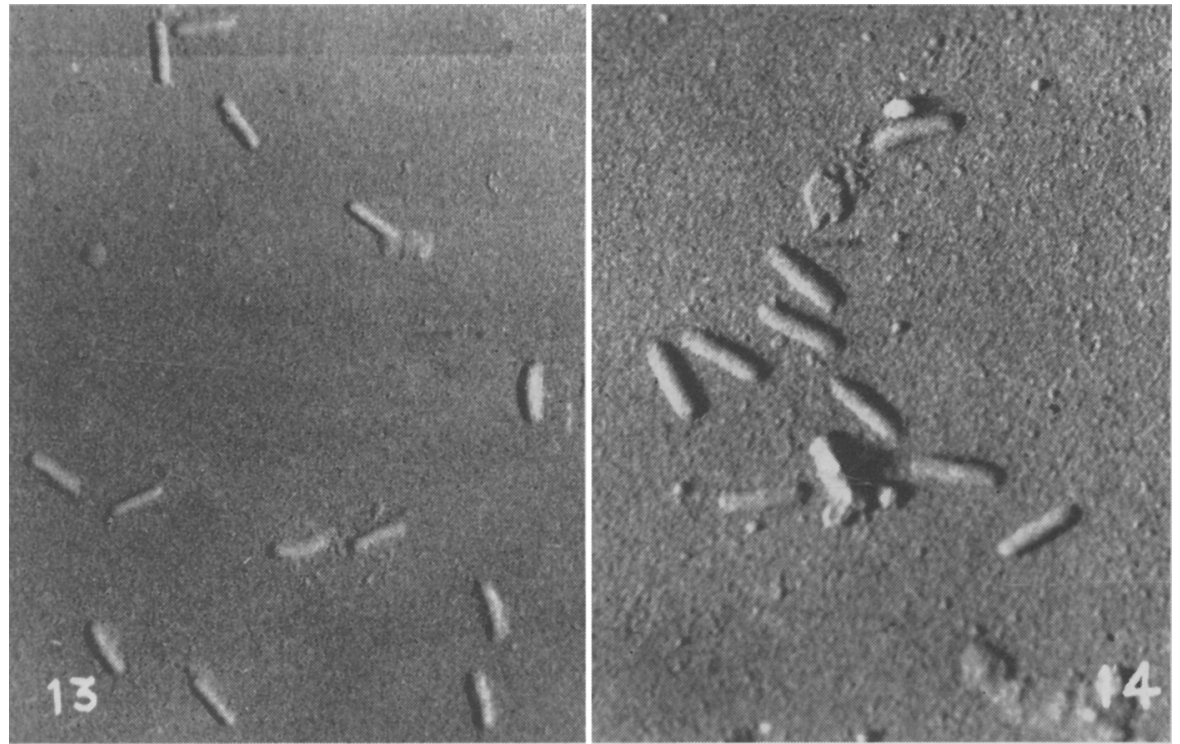

Fig. 13. An electron micrograph of a granulosis virus of Amelia pallorana.

Fig. 14. An electron mierograph of a granulosis virus of Recurvaria milleri.

Fig. 9. An electron micrograph of a granulosis virus of Laphygma frugiperda.

Fig. 10. An electron micrograph of material from a single specimen of Nephelodes emmedonia showing two partially dissolved capsules, at least one of which contains a granulosis-virus rod, and a polyhedron containing virus bundles.

Fig. 11. Another electron micrograph of a partially dissolved (in dilute sodium carbonate) polyhedron containing virus bundles, from Nephelodes emmedonia. (Because of the extremely small amount of infectious material, frequently part of a single insect specimen, with which to work, some of the illustrations in this paper admittedly are not up to the standards one might expect if adequate material had been available. Figures 10 and 11 , for example, represent micrographs prepared from material dissolved directly on the specimen sereen.

Fig. 12. An electron micrograph of a polyhedrosis virus of Hemileuca tricolor. 

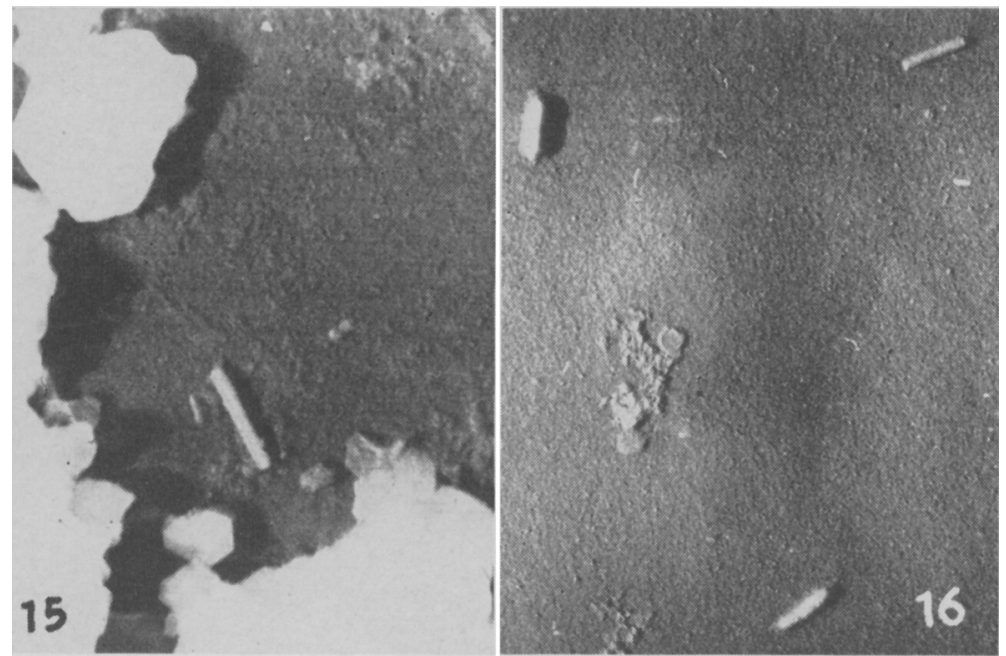

Fig. 15. An electron micrograph of a polyhedrosis virus of Rachiplusia nu, showing a single rodshaped particle.

Fig. 16. An electron micrograph of a polyhedrosis virus of Heliothis virescens. 
The journal Hilgardia is published at irregular intervals, in volumes of about 600 pages. The number of issues per volume varies.

Subscriptions are not sold. The periodical is sent as published only to libraries, or to institutions in foreign countries having publications to offer in exchange.

You may obtain a single copy of any issue free, as long as the supply lasts; please request by volume and issue number from:
Agricultural Publications
Room 22 Giannini Hall
University of California
Berkeley 4, California

The limit to nonresidents of California is 10 separate issues on a single order. A list of the issues still available will be sent on request. 